\title{
Problematising the Ethics and Conduct of the Ruling Party during Series of Malaysia's Post-political Tsunami By-elections
}

\author{
Badrul Azmier Mohamed@Bakar', Mujibu Abd Muis ${ }^{1}$, Jennifah Nordin ${ }^{1}$, Mahazril ‘Aini Yaacob ${ }^{1}$, Chuah Bee \\ Peng $^{2}$, Zaherawati Zakaria ${ }^{1} \&$ Nazni Noordin ${ }^{1}$ \\ ${ }^{1}$ Faculty of Administrative Science \& Policy Studies, Universiti Teknologi MARA Kedah, Merbok, Malaysia \\ ${ }^{2}$ Academy of Language Studies, Universiti Teknologi MARA Kedah, Merbok, Malaysia \\ Correspondence: Zaherawati Zakaria, Faculty of Administrative Science \& Policy Studies, Universiti Teknologi \\ MARA Kedah, 08400 Merbok, Kedah, Malaysia. Tel: 60-4-442-4312. E-mail: zaherawati@kedah.uitm.edu.my
}

Received: May 29, 2012 Accepted: July 3, 2012 Online Published: September 27, 2012

doi:10.5539/ass.v8n12p284 URL: http://dx.doi.org/10.5539/ass.v8n12p284

\begin{abstract}
The ethical aspect of election is inherently an uncommon topic to be brought up for discussion in Malaysia, and more so when it involves the ruling party. Essentially, the ethics of election is in itself an exceptionally rare subject since ethics and politics are not commonly discussed. The ethical dimension of politics is often camouflaged as the seemingly more important and desirable sub-topics of transparency and accountability in the discussion of good governance. This leads to an obvious slant towards administration (even though administration and politics are invariably inextricable). In Malaysia, good governance in politics is classified under the universal values that are in line with the claim for democratization. It has become an issue after 1997 following a few major global and national events specifically the 1997 Asian financial crisis, the sacking of the then Deputy Prime Minister Anwar Ibrahim, and the 1999 General Election. All these happenings awakened a quest for a more meaningful and more specific democratization focusing on the issue of ethics and election, pressing for a fairer and more transparent election. The increasingly forceful claim for such democratization crescendoed to the 2008 election results that crumbled the hegemony of the ruling party, Barisan Nasional. Consequentially, to regain the confidence of the public, the ruling party has spearheaded a few transformation programs, among them the concepts of '1Malaysia, People First Performance Now', and the Government Transformation Program (GTP). However, the target group of these concepts seems to be those in civil service rather than the leader of the country. Therefore, the ethical conduct of the ruling party observed during the series of by-elections held after the 2008 Political Tsunami best reflects and assesses the extent of dedication and adherence of the ruling party to the aspiration of 1Malaysia and transformation.
\end{abstract}

Keywords: ethics, election, democratization, transformation, government transformation program

\section{Introduction}

The political landscape of Malaysia after the 12th General Election on 8 March 2008 has been criticized incessantly for being distinctively different from its predecessors. Many scholars have come up with various models and assumptions about how the 'new politics' in Malaysia will take shape. While some see the 'Political Tsunami' as a precursor of a dual-party system, there are also certain sections that choose to perceive it as the initiation of the demise of of the primordial and irrational 'old politics' which is incongruent with the developmental politics. Politics in Malaysia is said to be moving toward a more mature form of politics which is non-communal. Thus, a form of democratization loaded with the elements of good governance or a. clean administrative management is taking place. With the awareness that the results of the 12th General Election marked the party's unprecedented defeat in the past 50 years, that the results was the manifestation of a protest; that the party's long-established monolithic hegemony is eroded gradually; Barisan Nasional as the ruling party of Malaysia is kept on its toes to seek avenues for transformation. This initiated the power shift from Abdullah Badawi to Najib Razak, with the assumption that the ruling party under a new leadership would be more responsive to the mass pressure for democratization and the people's demand for a fresh administrative management. Subsequently, it inspired the whole gamut of slogans and programs for change in the name of transformation. These included '1Malaysia, People First, Performance Now', New Economic Model, Government Transformation Programme, and Economic Transformation Programme. A close analysis of the 
principles and the programs disclosed a clear objective for change which leans toward democracy and a superior administrative management. It is packed with elements such as ethics, sense of responsibility, accountability, transparency, and integrity which collectively counter corruption and instantly mobilize efficiency, effectiveness and productivity.

Najib Razak took over the post of the Prime Minister of the Federation of Malaysia on 1 April 2009. This brings the transformation program to its third year. In fact, the principle of '1Malaysia, People First, Performance Now' has been publicized longer than people thought, through public speeches, songs and commercials. Therefore, it can be concluded that the winds of change initiated by Barisan Nasional have swept through the nation even earlier than most thought. Regretfully, behind every revolutionary program, there lie the paradoxes. The politics of Malaysia which has been expected to be less communal following the changes made in public administration has turned out to be otherwise. The political scene in Malaysia after the Political Tsunami has been one that that is peppered with a series of by-elections conducted on various grounds. Each episode from the first to the last in this series showed the same drama, and each demonstrated greater inclination towards the era before March 2008 . In fact some perceived it as 'the return of Mahathirism'. Clearly, from the perspective of public administration, there seemed to be some form of change but from the political angle, the previous political approach and strategy appeared to be more stifling.

With all that happened, it has given rise to the question of how far the changes have taken place as alleged, and whether the changes are underway at all. Thus this article sets out to discuss the direction of the transformation program, and to identify the kinds of change through the indicator of change, i.e. the ethics of the leaders in public administration. Obviously, the series of by-elections post-March 2008 provided ample opportunity to the researchers to conduct a content analysis and observation on two major actors of change, namely the ruling party as political executives, and public administration as non-political executives. The analysis was done by operationalizing basic concepts of political relationship and public administration, such as neutrality, dichotomy, and shared accountability; while the scope of discussion of this article encompasses the ethics exhibited by the ruling party, i.e. Barisan Nasional in its participation in the election at the federal level and the involvement of public administration in the series of by-election.

\section{Transformation of Public Administration and Politics}

Change is common in any entity or organisation, so is in public administration. Social and economic pressures and political demands are among the variables that have been identified as the drivers of change. In the process of mobilizing change in the names of transformation and reformation, the leader or the polical excecutive play a major role. The leader acts as the top management who steer the direction of change. This is a top-down process in accordance to the transformation program. Therefore, the ruling of the government plays a major role in any agenda assuming the name of transformation. Any confusion about change and the method of change at the level of the leader and the ruling party is capable of jeopardizing any transformation program. Conscious of the change demanded by the people, or rakyat, Najib Razak launched Government Transformation Program (GTP hereafter) in April 2009 based on the key tenet of '1Malaysia, People First, Performance Now'. This program has a two-fold objective, firstly, to transform the civil service towards greater efficiency and effectiveness in terms of services, as well as its responsibility towards productivity. The second objective is to make Malaysia an advanced nation, one that upholds unity and equality at various levels, and whose people enjoy a high standard of living. Chor Chee Heung, the Minister of Housing and Local Government announced that the government targeted to achieve the per capita income of USD15,000 by year 2020 (Chor Chee Heung, 2010). The GTP emphasizes good practice in administrative management. Therefore ethics and accountability has been brough to the forefront in civil service. According to Md Ishak Ismail and Nur Fai'zah Abu Bakar (n.d.), good administration does not limit to abiding to the law, it is directly related to the question of personal ethics and accountability. Anderson and Heywood (2009) on the other hand characterise good administrative management as one that exhibits various components like engagement, accountability, transparency, equality, efficiency, consensus, responsive and effective. Owing to this, many scholars opine that this transformation plan carries economic, political, social and administrative aspiration.

For this purpose, National Key Results Areas (NKRAs hereafter) have been identified. These areas are focused on as they are the catalysts in the transformation process. The six key results areas are reducing crime, fighting corruption, improving student outcomes, raising standards of low-income households, improving rural basic infrastructure, and improving urban public transport. However, there are criticisms on the lack of emphasis by the ruling party on battling corruption through the concept of clean administrative management whereby Lim Kit Siang (2009) questioned why there was not anyone from the government to take a stand on 'zero tolerance for corruption'. On the other hand, the Economic Transformation Program (ETP hereafter) which aspires to move 
Malaysia forward to become a high-income nation with the gross domestic income per-capita of USD15,000 by the year 2020 is expected to generate as many as 33,000 new job opportunities. This heralds an overflow of economy that enables the eradication of poverty. Nevertheless, this program is alleged to only benefit certain quarters who are close to the leaders of the ruling party. This perception is a result of the status quo of a one-party system of government which has been maintained since Independence. In fact ETP has also been criticized as merely a political rhetoric, that any change that it puts forward is only cosmetic and not substance.

\subsection{Administration of General Election in Malaysia}

One of the pre-condition of 'democracy' is to hold general election (GE hereafter) periodically. General election has been identified as capable of creating a political space and opportunity for the rakyat. This is the time when the people can directly participate in politics or get directly involved to determine the direction of a country. As a democratic country, Malaysia is responsible and obliged to ensure any election held is free and fair. According to Abdul Aziz Bari (2005, p.65), a free and fair election is crucial to ensure credibility of mandate given to govern. An election whose fairness is in question will have the mandate doubted (Abdul Aziz Bari, 2005, p.65). On the other hand, Ab. Rashid Ab. Rahman (2007, p. 92) sees level playing field in elections as the people's wish. These two realities clarify the cry for democratization as seen in the Middle-Eastern countries which began in Tunisia at the end of 2010. The people took to the street as they no longer believed in elections.

Hence, Articles 113 to 120 of the Federal Constitution assign the setting up and the conduct of Election Commission (EC hereafter) which is an independent entity that answers directly to the legislative branch, i.e. the Parliament. Free from the power of the executive branch, the appointment of Chairman, Deputy Chairman, and 5 members of EC is the mandate of the Yang Di Pertuan Agong after consultation with the Conference of Rulers (Sidang Pengarang ILBS, 1992). In dealing with human resources affairs such as the appointment of staff, it has the autonomy in management and administration. Subsequently, the 3 main functions of the EC as constituted in the Federal Constitution are to divide the constituencies, to hold the registration of electorates and, to conduct the election, both general election and by-election (Jayum Anak Jawan, 2007, p. 77). The obstacle often faced by the $\mathrm{EC}$ is resulted from its complex relationship with the executive. It involves the freedom and the ability of the entity to 'appear' independent. Opinions on this differ. According to Ab. Rashid Ab. Rahman (2007, p.94), there is no clear statement in the Federal Constitution claiming the $\mathrm{EC}$ as an independent body. However, Abdul Aziz Bari (2006, p.282) sees the existing provision of Consitution clearly stresses on the need for a commission that can gain public confidence. According to K. Ramanathan (2002), Maizatul Haizan Mahbob (2005), and Ghazali Mayudin (2006), this follows the weakness of a parliamentary democracy system which upholds separation of power. In other words, fusion of power gives rise to an overlap in power between the executive branch and the legislative which causes the centralization of power to the executive. There are a few explanations of the scenario related to the executive and the legislative. Among them are that the executive is a part of legislative; the executive emerges from the majority group of the legislative branch; the majority group is from the winning party of the election, the executive constitutes the party leaders who have won the majority. Therefore, the loyalty of the ordinary member of the legislative from the ruling party is bound to the ruling party in any decision-making in the Parliament. As a result, the check and balance mechanism between the two branches is no longer fully functional. This is worsened by the control from two third of the party leaders. Therefore, even with the existence of the opposition as part of the legislative content, it is not able to carry out the function of check and balance effectively.

Another problem can be elucidated from the perspective of human resources. Abdul Aziz Bari (2006, p.283) concedes that the Constitution has provided the necessary 'protection' for the commission to be independent and neutral, the rest is dependent on the attitude and the mindset of its members and administrators. Traditionally, the office of the Chairman and members of the panel of EC is taken by former civil servants (Abdul Aziz Bari 2006, p.283). Although the Prime Minister is not directly involved in the appointment of the Chairman and members of the panel, there lies a strong belief that the appointment is largely based on the 'advice' of this chief executive. At the same time, the administrators are directly chanelled from Public Service Department which is directly responsible to the executive branch. Abdul Aziz Bari (2006, p.67) affirms the detrimental aspect of freedom and neutrality as a product of the tradition of appointing members of the panel from former civil servants and its administration is principally public officials. Additionally, the fact that the Commission is chiefly financed by the executive branch further jeapordizes the situation.

It is widely understood that the EC does not only directly respond to the Parliament but is also tightly bound by the orders of the cabinet. This is the greatest constraint of EC in terms of independence, seemingly indepent and neutral which consequently eliminate the possibility of competition in level playing field and a free and fair election. Therefore, the Prime Minister, together with other cabinet members, is responsible to make this happen. 
Maizatul Haizan Mahbob (2005, p.93) points out that it is not possible for the ruling party to be neutral as it uses its power and influence to form the EC in such a way that what should be an independent body does not operate as how it should be. Consequently, Abdul Aziz Bari (2006) stresses that in a parliamentary democracy system, the government leader himself is the the one bestowed with the power and ability to create a commission that is free, neutral, and responds to the constitution. Therefore, it justifies why the election reflects the accountability of the ruling party (Abdul Aziz Bari, 2006, p.69).

\section{Background of the Series of By-elections Post 'Political Tsunami'}

The series of by-elections in Malaysia is not a foreign concept but has been practiced by other countries, especially the Commonwealth countries. These countries which were once colonized by the British mostly embrace parliamentary democracy, thus have an election system that is fundamentally identical, even though some changes have been made according to current development. Countries like United Kingdom, the Republic of Ireland, Canada and India for instance hold by-elections in cases of the demise or the resignation of elected representatives. In the United States and the Philippines, this system is better known as special election. Therefore, by-election functions as the reinforcer of the democracy process and culture. However, by-election is not necessary in the case of vacant seat at the time of current mandate which lasts for less than two years. The results in the 13th General Election hit rock bottom in the record of Barisan Nasional's 50 years of leading the country with two-third mandate. This served as a wake-up call that shook the ruling party up to look for ways to change, hence the birth of Government Transformation Program (GTP) as the guidelines for changes. Meanwhile, the implicit program for change that aims to sustain the hegemony of Barisan Nasional in the political arena of Malaysia was challenged by the 16 by-elections. Therefore, it provided the opportunity to discern the extent of change that was underway. As commented by Abdul Aziz Bari (2006, p.69), election is in fact one of the avenues where accountability is enforced.

There have been 16 by-elections since 8 March 2008 where most were held following the death of the legislative members at either the federal or the state level. A small portion of them was due to the registration of the legislative members based on certain reasons. EC is solely responsible for the implementation of by-elections whether for the election for representative at the Dewan Rakyat (the federal legislative body) or to elect representative for the Dewan Undangan Negeri (the state legislative body). It is the body in which the jurisdiction of the federal government is vested.

Table 1. Delineates the level of by-elections and the reasons they were held

\begin{tabular}{lllll}
\hline No. & Date & By-election & Level & Reason \\
\hline 1 & $26 / 08 / 2008$ & Permatang Pauh & Federal & Resignation \\
2 & $17 / 01 / 2009$ & Kuala Terengganu & State & Deceased \\
3 & $07 / 04 / 2009$ & Bukit Selambau & State & Resignation \\
4 & $07 / 04 / 2009$ & Bukit Gantang & State & Deceased \\
5 & $07 / 04 / 2009$ & Batang Ai & State & Deceased \\
6 & $31 / 05 / 2009$ & Penanti & State & Resignation \\
7 & $17 / 07 / 2009$ & Manik Urai & State & Deceased \\
8 & $25 / 08 / 2009$ & Permatang Pasir & State & Deceased \\
9 & $11 / 10 / 2009$ & Bagan Pinang & State & Deceased \\
10 & $25 / 04 / 2010$ & Hulu Selangor & Federal & Deceased \\
11 & $16 / 05 / 2010$ & Sibu & Federal & Deceased \\
12 & $04 / 11 / 2010$ & Batu Sapi & Federal & Deceased \\
13 & $04 / 11 / 2010$ & Galas & State & Deceased \\
14 & $30 / 01 / 2011$ & Tenang & State & Deceased \\
15 & $06 / 03 / 2011$ & Kerdau & State & Deceased \\
16 & $06 / 03 / 2011$ & Merlimau & State & Deceased \\
\hline
\end{tabular}

Source: www.spr.gov.my

Out of the 16 by-elections held, the ruling party won 8 and the rest won by the merger of the opposition parties, 
sustaining the victory of the opposition in these by-elections. In fact the outcome of the 13th GE has allowed the opposition coalition to rule five states in the country. However, this is insufficient to affirm the claim that the administration of election in Malaysia is free and fair, and there is a level playing field.

\section{Political Vehicle of the Ruling Party during the By-elections}

Any ethical issue arise during the election, either general or minor, either to elect the representative for the Parliament of Dewan Undangan Negeri, has been identifiably public administration which prioritizes the importance of the ruling party. Ab. Rashid Ab. Rahman (2007) and Abdul Aziz Bari (2005) both concur that this is the main hindrance to the accomplishment of a free and fair election. Within the context of this article, the vehicle of the ruling party refers to any public administration entity which is based on the legislative constitution with the neutrality underpinning. The practice of such principle is believed to enable an efficient and effective public administration. Therefore, by-election can be used as an experimental ground to assess the role of public administration as non-political executive. The series of by-elections opened the avenue to investigate the ethics of public administration as a neutral entity. Apart from that, by-election is also a competition or a race among the political parties. Therefore, a logic mind would know that only the party's political vehicle is involved. In Malaysia, the Election Act 1957 provides a set of clear guidelines on the ethics and conduct during elections. However, there have been complaints about the mobilization of public administration by the ruling party for its own advantage and benefit. On the part of public administration, ready assistance is sincerely offered to the ruling party in elections. As a consequence, election has become a contest between the political vehicle of the opposition and that of the ruling party. Nik Abdul Aziz Nik Mat, the spiritual leader cum a de-facto leader of Pan-Malaysia Islamic Party (Parti Islam Se-Malaysia, PAS hereafter) commented that the by-election processes of Merlimau and Kerdau breached the ethics of democracy (Norliza Wasilan, 2011). According to him, both by-elections were competitions between PAS and the government leaders, not the ruling party (Norliza Wasilan, 2011). Such remark entails the role of political vehicle as a form of assistance to the ruling party in elections, besides being its support.

It is found that nearly all public administration agencies facilitated the ruling party directly or indirectly during the series of by-elections post-March 2008. The kinds of assistance offered were based on their respective areas of control and duty. During the by-elections, these public officials carried out their duties according to the areas of control and duty of the public agencies they represented. The services provided by the public administration exhibited efficiency and speed at its best. However, they were also perceived to have been overdone during the election period; that it appeared to be odd as all forms of bureaucracy vanished all of a sudden, albeit momentarily. For instance, matters that appeared to be impossible to be solved in a jiffy, matters publicly known to need to take a long time to solve, and matters frequently claimed by the public administration to be of complicated process. Strangely, all sorts of application, problem, and issue did not only receive undivided attention from the ruling party, but miraculously resolved instantly. There are various forms of assistance given by public administration to the ruling party. The agency responsible for rakyat's welfare is one of the conventional vehicles for the Barisan Nasional's election campaign. It provides a personal touch which is absent in other domains of public administration. Financial aid and household necessities are among the common tokens. The Social Welfare Department which is highly populated with female employees has long been synonymous to the political vehicle of the ruling party. Besides that, the Works Department also plays a major role in any election. Patching, resurfacing and widening of roads are some of the common works to be done speedily. Any request from the rakyat often gets instant approval. In the context of the series of by-elections post-March 2008, these scenarios were observed to have burgeoned at an unbelievable rate and scale. Public administration that has long been perceived as remote from the the rakyat suddenly became close to them. The rakyat no longer needed to hound for the public agency to solve their problems because the public agencies reached out to those people who needed their services. There was not a single trace of red tapes and bureaucracies. Resulting from these, the rakyat even poked fun at the deaths of the people representatives, seeing them as a form of blessing. By-elections were seen as an economic overflow to the related constituencies. Nevertheless, all these were temporary as immediately after the by-election fever, everything went back to how they were before. Therefore, it validates the premise that involves problematizing the ethics of public administration. The provision of the best services to the rakyat is the basis of public administration. But offering exceptionally efficient services to the rakyat only during the election period will raise adverse perceptions. It will be seen as the services given by the ruling party to win the election. This evidently contradicts the ethics of public administration which emphasizes on the principle of neutrality.

Similarly, law enforcers like the police force are also seen to embrace the same practice. Greater leniency is readily granted to the ruling party as compared to the opposition in which it is a general and integrated practice 
for the police force to be selective in their charges. This facilitates the opportunity and broadens the scope of the ruling party in the election campaign. During the series of by-elections post-March 2008, such practice was witnessed to be continuously embraced by the police. For example, during the by-election held at Dewan Undangan Negeri Merlimau, the supporters of the opposition party accused the police of being partial in their enforcement where the designated areas for supporters set up at the polling station only applied to the supporters of the opposition, but not those of the ruling party. The same happened during the tug-a-war between the police force and the opposition party on the issuance of the permit to hold political talks in which the peace and safety of the public was used as an excuse to deny the opposition those permits. The actual hindrance was the attitude of the ruling party. This was clarified by Nazri Aziz (a minister in the Prime Minister's Office) in his response to the question raised by the member of Parliament for Bukit Katil in Dewan Rakyat where he commented that such actions of the ruling party manifested the involvement of public administration in election (Azlinda Salim, 2011, March 29). Nazri Aziz also explained that speedier approvals of applications were not part of the political strategies of the ruling party. Also according to him, such behavior was acceptable because if the approvals were not given now, they would have to be granted eventually anyway. This reality projects a kind of effort to legitimize certain actions that can be classified as a breach of ethics. Lastly, there is a difference between the official national media and the media for the ruling party. However, the one and only official national media that is Radio Televisyen Malaysia (RTM) has long been seen as 'belonged' to the ruling party. Even in its effort to introduce GTP, a close analysis of the content reveals a strong partial and pro-ruling party slant taken by Radio Televisyen Malaysia (RTM). The manipulation of RTM by the ruling party was also evident during the series of by-elections post-March 2008. Therefore, the issue of ethics arose since the operational costs of this official national media are borne by the taxpayers, i.e. the rakyat, and not the ruling party.

\section{Government Funds and Assets}

Any political party that wishes to participate in the election needs a substantial sum of money. All activities related to the election such as political campaign involve various resources that require huge financial support. Among the common activities during election are advertisements on printed and electronic media; preparation of campaign materials such as billboards, banners, posters, pamphlets, and organizing talks. These activities also involve the mobilization of the party's political vehicle from which the various expenses on travels, accommodation and allowances are drawn. Therefore, in countries where democracy has matured, funds are generally are raised through donation drives and dinners. Subsequently, these funds have to be audited and the income to be reported to the public.

In Malaysia however, the financial resource and fund management needed for the purpose of election by the ruling party still remains fuzzy. There is no clear standard guidelines and practice in this aspect. In fact it is not surprising that among the rakyat there are those who are misguided into thinking that the public funds belong to the ruling party, the same goes to public assets. Actions and statements made by the leaders of the ruling party and public officials have generated misperceptions and confusion among the rakyat that continue to sustain and legitimize any unethical practice. By right, a country should be governed the way how a private limited company is managed. Ethics in management procedures requires a clear separation between personal and company funds and assets. Any kind of company resources be it money, employees, or assets is not allowed to be used for personal gains. The ruling party Barisan Nasional and the public administration will always be restrained by the problem of ethics if both choose not to emphasize on ethical practices. In fact ethics is one of the highly important aspects of the implementation of good administrative management concepts. There are however limited related literatures on ethics in public administration which is directly involved in politics. However, there are articles which discuss good administrative management. The hegemony of Barisan Nasional in politics and public administration is one of the contributing factors of the emergence of ethical quandaries that are prevalent today. As a long-standing ruling party, Barisan Nasional has grown to be complacent. The same applies to the public administration under the management of Barisan Nasional. Up to now, people are still unclear about the financial resources of the ruling party. However, numerous allegations have been made on the political position of Barisan Nasional, accusing it for providing huge benefits to the party itself. Under the security blanket of the position as the ruling party, efforts to raise funds for the party are not essential as large part of the party's funds can be saved. Nevertheless this advantage obviously gives rise to ethical issue steered towards power abuse. During the series of by-elections post-March 2008, the party's funds were saved through the various programs organized by different public departments or agencies. In a glance the programs were organized for the benefits of the public. But a careful scrutiny on the main ideas of the contents of speeches given at these events by the leaders disclosed that these programs were more of the party's political campaign for the election than they were for the good of the public as claimed. These events were organized even more frequently during the period of 
election campaign, as though to celebritize or glamorize the various allegations on the misuse of government funds for the gains of the ruling party.

Apart from that, observation of these programs organized by public departments and agencies revealed that not only the content and the tone of the speeches that characterized them more of talks befitted political campaign, but they were also very often interjected with the announcements on the allocations for certain projects for the relevant constituencies. These events were also used as a platform for the presentation or distribution of aid to the local people by the public agency involved. Implicitly, it was a noble event organized for the government to fulfill its duty and responsibility to the rakyat. However it explicitly invited problems related to ethics as it was done in a grand scale during the by-election campaigning season. The various events organized during this period verified the direct benefits enjoyed by the ruling party which aimed at facilitating the victory of the party in the by-election.

To discuss this further, the leaders of the ruling party who are at the same time holding office in the cabinet or members of the executive body are also shackled by the problems of ethics. For example, Najib Razak's appearance in the campaigns at the time of by-elections was questioned. Did he attend as the Prime Minister on duty for the good of the public or as the Chairman of Barisan Nasional/President of UMNO for the benefits of the party? Subsequently, it gave rise to the question as to who should bear all the costs for his visits such as logistics (plane/helicopter/car), accommodation, pocket money, and other claims. Whose fund shoud this be drawn from? The government's or the party's? Ethical issue related to the government programs managed by public administration during the election season also involved various activities that also involved the kinds of activity that aimed to attract large volume of audience to fill up the venue where the program took place. It is an open secret that there was a general lack of public response to events or programs organized by the ruling party. This kind of event was not only incapable of drawing the crowd, in fact it also received poor response among the members of the party. To overcome this problem, all sorts of facility were provided such as nice venue, free shuttles, food, and even pocket money. This has been a common practice since the leadership of Mahathir Mohamad, especially after the removal of Anwar Ibrahim from all his posts in the government and in the party. Again, should this be spent using the party's fund or the public fund?

Other observations indicated that the ruling party has had easy access to all government-owned premises, facilities and public assets under the administration of public administration. Till now there are still misinterpretations by the rakyat whereby some still think that community centres, community halls, fields and other public assets are owned by the ruling party. Very often these public premises are used for various events or programs whose content demonstrated their benefits to the ruling party. The same goes to the transports owned by the government agencies such as cars, helicopters, and airplanes that have been found to be utilized by the ruling party for logistic purposes during the by-election campaigns. Apart from that, the mobilization of the enforcement agencies to look after the needs for public security and peace also requires a huge expenditure. However, these peacekeeping exercises very frequently turned out to restrict the freedom of the opposition parties to convey their agenda and information to the voters. Thus, it prevented the rakyat from enjoying their rights to receive equal and impartial information necessary for their consideration as voters to elect the suitable party or candidate for themselves.

Ethical quandaries also involve the immediate announcements of project allocation and implementation. There are many terms given to this sort of practice. Among them are 'gula-gula' (candies), 'politik budi' (compassion-based politics), 'projek mi segera' (instant noodle project) which are components of developmental politics that have become core culture in the politics of the ruling party since the era of Mahathir Mohamad. Good news abounds during by-elections that apparently some people start to wish for the early death of the people representatives of their respective areas. Allocations for all kinds of project which allegedly bring economic benefits to the local community are announced. This is also the time when local residents get to enjoy smooth rides on well-resurfaced roads. They also receive all sorts of aid from respective public departments and agencies while 24 hours prior to balloting, the ruling party is said to offer various kinds of 'contribution' to voters. For instance, Sing Tong Him (Kota Melaka), a Member of Parliament lodged a police report after receiving complaints about an agent of the ruling party had been found distributing RM100 to the voters. This, according to Sing Tong Him, was equivalent to vote-buying. Such happenings have also brought about the moniker 'buy-election' for 'by-election'.

While all these efforts of the ruling party which aimed to show 'people first', they were overdone during by-elections, hence the ethical quandaries. Therefore some even call it political bribery. This kind of conduct definitely does not produce a free and fair election. Consequently, an atmosphere of paradox pervades with the continuity of practices of developmental politics in the era of Government Transformation Program (GTP) that 
aims for a good administrative management in which ethics is prioritized. On one hand, the ruling party strives for a high-quality administrative management that puts the rakyat first and stresses on achievement. But with each by-election, the ruling party is seen to have been compromising ethics to put the votes first and to stress on the seats. All these that have taken shape after developmental politics do not only trap and constrict the ruling party but also the public administration. Thus, from the conduct of the ruling party throughout the series of by-elections, it seems like the party itself does not really believe and have faith in ethical administration but focuses more on good administrative management that works to entice the voters. Ironically all these unethical conducts were unashamedly reported by the media controlled by the ruling party. This incident strongly implies that the lack of interest in upholding ethics not only in the government and the public administration, but also in the Malaysian society in general.

\section{Transformation: Democratization or Autocration?}

From the observation of the patterns of change in any country especially those in East Asia, including South East Asia, any change in the name of either transformation or reformation is based on a democracy that is packed with various concepts of good administrative management, in which ethics is incorporated. Japan, South Korea, Taiwan, and Indonesia are among the countries are committed to implement change based on democracy. As such, these countries have also had the same experience like Malaysia. Rapid development in these countries and Malaysia was confirmed by Sity Daud $(1999,2002, \& 2006)$ as the outcome of developmental state. This concept does not enable the government to interfere in economy but also taking part in it. Corporate nationalism, government owned company, and government linked company are the various manifestations of government's participation in economy. Developmental state has propelled these countries, including Malaysia to achieve rapid economic growth in 1990s (albeit it occurred earlier in Japan in 1970s and 1980s). This concept has successfully transformed the then agragrian society in these countries to the industrial society now.

Therefore, it cannot be denied that the contribution of an autocratic government is often defined as strong government in economy. After World War II, Japan saw a swift development due to its one-party government dominated by the Liberal Democratic Party. On the other hand, the government of South Korea was frequently influenced and manipulated, even completely under the militant government; while the one-party system under Kuomintang successfully eradicated poverty in Taiwan. Likewise, Indonesia also experienced an economic boom under Suharto's 'guided democracy'. Back in Malaysia, eventhough how Mahathir Mohamad steered Barisan Nasional totally turned the economy of Malaysia around, a more careful study revealed that the basic model of economy at that time was industry-based. Such industrialized economy which is also manufacturing-based, electronic-based, and export-based is one in which foreign direct investment plays a very big role. Therefore, it can be concluded that the recipe of economic excellence in South East Asia at that time was purely based on the practice of developmental state, an autocratic government, and an industry-based model of economy. Besides the three basic ingredients mentioned earlier, this excellence would not have been accomplished without the understanding of the neo-liberal economy that had pulled in the foreign direct investments from the western countries to East Asia to fully utilize the cheap labor and to explore new markets. It was part of the transition process of the western economy toward a model of economy based on service and information technology. Furthermore the labor force in the west was no longer used to routine works at the assembly line in the manufacturing sector. Taking advantage of this, Asian countries found themselves a too-good-to-be-missed opportunity to benefit in terms of job opportunities, technological transfer and subsequently vibrant economic activities. Interestingly, these investors of the manufacturing sector fundamentally had great confidence and particular liking toward autocratic governments even though they were from democratic countries. This was greatly due to their confidence on these governments in managing the workers whereby the autocratic government leaders were able to effectively control the labor unions.

In one generation, the reception of this development had physically changed the East Asian countries. This rapid development had visibly generated a lot of socio-economic changes. However the subsequent economic development had also brought forth many negative effects claimed by many as the cause of the weaknesses of the government and its own public administration. Among the major weaknesses was in terms of administrative management which gave rise to various corruption issues. The autocratic governmental style or extremely strong government that monitored every single sector of the country initially was able to be the impetus for a rapid economic development. Regretfully, it also engendered corruption (with the exception of Singapore in which the autocratic governmental style has been used to curb corruption). The potical executive which has been in power for too long, and the non-political excutive which have been too long under the same government create a comfort zone that leads to the occurrence of transactional politics as suggested by Bailey, F. G. (1970), Boissevain, J. (1978), and Ahmad Nidzamudin Sulaiman (2002). For politicians and public administrators, a 
government ruled by the same political party, worse still, the same political leaders, will expose them to ethical quandaries and subsequently will lead them to the quicksand of corruption. Transactional politics refers to a behavior in which whether political executives, non-political executives, or even people who are close to this group of leaders coincidentally violate the ethics simply because each and every one of them is aware of the available opportunity to do so since they have identified all possible loopholes in the system. In Malaysia, money politics has been a phenomenon of the ruling party since 1990s. It was made possible by the close relationship between the government and the corporate companies which were in fact owned by the political leaders through their position as the company shareholders, or better known as government-linked companies. This close connection also explicates how politicians can become corporate figures and corporate figures can become politicians and consequently manipulate and control public administration. This also promotes better success among those who know-who rather than those who know-how. Hence, the onslaught by foreign-exchange speculators was not the only factor that had led to the 1997 Asian Financial Crisis.

Majority of the East Asian countries chose to implement change based on demoratization as their strategy to overcome the economic downturn post-1997 Asian Financial Crisis. In other words, each discarded the autocracy that was loaded with transactional politics and the neglect of ethical practices in administrative management. Whether the change was due to sheer awareness or the compliance with the pre-conditions of International Monetary Fund (IMF), the most important thing is that countries like South Korea, Taiwan and Indonesia have improved in leaps and bounds economically and their people have also been able to enjoy a better level of democracy. Using Employee Provident Fund (EPF) to save the economy demonstrates the rigidity of Malaysia as an autocratic practitioner. It is in line with the Mahathirism image famous for its strategy of controlling the entire national sectors. However, the government under the leadership of Abdullah Badawi seemed to attempt to move toward democratization. Some steps taken by the administration under Abdullah Badawi to democratize and revive administrative management were the change in the status of Anti-Corruption Agency (ACA) which was directly under the executive care to a freer and more neutral Malaysian Anti-Corruption Commission (MACC), the same with the National Integrity Plan (PIN), and the release of Anwar Ibrahim. Nevertheless, these efforts of democratization and the revival of administrative management by Abdullah Badawi were rendered futile due to certain weakness in his leadership as he was in office as the Prime Minister only for one term.

In contrast, the New Economic Model (NEM) drafted by the administration of Najib Razak was found to be more in sync with the current climate of globalization. This economic model also served as a reflection of the awareness of Malaysian leaders of the changing climate. Malaysians no longer embrace the same features as those in last one or two decades during the glorious era of Mahathir Mohamad's administration. At that time, the basis of economy was based on industrialization (manufacturing/export basis) which was in line with the socio-economic and education level of Malaysians where generally not many had tertiary education. Thus, the economic plan by the administration of Najib was drafted to accommodate the current population who has higher education, is more expensive and no longer appropriate to work in the manufacturing sector. This new model also shows that the leader is more aware of drawing the type of foreign investor that matches the type of existing population. The NEM attempts to change from industrial/manufacture basis to the basis of service, innovation, and a more vital role of the small and medium enterprises (SMEs).

However, discerning the conduct of the ruling party during the series of by-elections post-March 2008 revealed a paradoxical mood. The existing ethical quandaries clearly contradict the aspiration outlined in the NEM. Mahathirism that is packed with the the elements of control/manipulation of public administration and all other government-related agencies are confirmed to encumber the aspirations listed in NEM. While the target investors are mainly from the service and innovation sectors, the conduct of the government still maintains the elements of Mahathirism which are more appealing to investors of industrial/manufacturing/production sectors. Ironically, while aspiring to promote the service and innovation sectors and to emphasize on the role of SMEs, the ethical quandaries that manifest the excessive manipulation of the public sector by the government will only inhibit the accomplishment of this aspiration. It expounds the administration of Najib Razak which is still influenced by Mahathirism, a practice that is outdated according to the starkly different economic and social climate. Therefore, the transformation by the GTP is perceived as more inclined towards autocratization than democratization.

\section{Conclusion}

In this article, the ethical quandaries faced by the ruling party and public administration have been thus operationalized to assess the extent of transformation that has taken place in the administration of Najib Razak. The 16 by-elections held after the 12th General Election have provided the opportunity to operationalize these ethical quandaries in order to gauge the transformation that is shaped in the name of Government Transformation Program (GTP). A close observation and analysis on the conduct of the two main actors who are closely related 
has unraveled the truth that both political executives and non-political executives are equally muddled in their interpretation of change. The only comforting truth is that both strongly stress on delivering the best service to the rakyat. Ironically, in the process of doing so especially during the series of by-elections, the Machiavellian side of the ruling party has been unveiled. As such, the listed objectives of GTP are essentially noble since they collectively aim to provide the best service to the rakyat. However, to achieve these objectives, the long haunting ethical quandaries emerge along the way. This occurrence was even more obvious during the series of by-elections post-March 2008 where miraculously swift service to the rakyat was provided without considering the ethical implications. As a result, GTP has exhibited a different nature, or it has appeared to have certain hidden agendas, i.e. to become the latest tool of the ruling party, Barisan Nasional. In other words, GTP is not a transformation program but a program to sustain Barisan Nasional which is full of rhetorics in weathering the season of change. From another perspective, it can be construed as the two main actors which are the ruling party and public administration do not have a clear idea of the reason for change and the means to change. This only induces the conduct for change that is confined to politics and eventually fails to bring about any change as aspired. In conclusion, Government Transformation Program (GTP) is a change program that has only managed to produce the status quo thus far.

\section{References}

Ab. Rashid Ab. Rahman. (2007). Integriti pilihan raya dan system pilihan raya Malaysia: Perlukan pembaharuan? In Anis Yusal Yusoff, Mohd Rais Ramli, \& Zubayry Abady Sofian (Eds.), Integriti politik di Malaysia: Ke arah kefahaman yang lebih sempurna (pp. 88-100). Kuala Lumpur: Institut Integriti Malaysia.

Abdul Aziz Bari. (2006). Politik Perlembagaan: Suatu perbincangan tentang isu-isu semasa dari sudut perlembagaan dan undang-undang. Kuala Lumpur: Institut Kajian Dasar.

Ahmad Nidzam Sulaiman. (2002). Hubungan transaksional: Mencabar model sistem dalam analisis politik gabungan. In Ghazali Mayudin (Ed.), Politik Malaysia: Perspektif teori dan praktik (pp. 75-94). Bangi: Penerbit Universiti Kebangsaan Malaysia.

Anderson, S., \& Heywood, P. M. (2009). The Politics of Perception:Use and Abuse of Transparency International's Approach to Measuring Corruption. Political studies, 57, 746-767. http://dx.doi.org/10.1111/j.1467-9248.2008.00758.x

Azlinda Salim. (2011, March 29). Edisi7 [Television broadcast]. Shah Alam, Selangor: Natseven TV Sdn. Bhd.

Bailey, F. G. (1970). Stratagems and spoils: A social anthropology of politics. Oxford: Basil Blackwell.

Boissevain, J. (1978). Friends of friends: Networks, manipulators and coalitions. Oxford: Basil Blackwell.

Chor Chee Heung. (2010). Perhimpunan bulanan Kementerian Perumahan Dan Kerajaan Tempatan " 1 Malaysia: Menjana Transformasi”. Retrieved March 16, 2011, from http://www.kpkt.gov.my

Ghazali Mayudin. (2006). Demokrasi dan pilihan raya di Malaysia. In Ghazali Mayudin, Jamie Hamil, Sity Daud, \& Zaini Othman (Eds.), Demokrasi, kepimpinan dan keselamatan dalam politik Malaysia (pp. 50-65). Bangi: Penerbit Universiti Kebangsaan Malaysia.

Jayum Anak Jawan. (2007). Malaysian politics \& government. Shah Alam: Karisma Publications.

Lim Kit Siang. (2009). Laporan Ketua Audit Negara 2010. Retrieved March 17, 2011, from http://www.audit.gov.my

Lim Kit Siang. (2009). Why nobody in government starting from Najib ever talked about "zero tolerance for corruption" to demonstrate their seriousnessabout battling corruption. Retrieved March 16, 2011, from http://blog.limkitsiang.com

Maizatul Haizan Mahbob. (2005). SPR dan pengurusan pilihan raya di Malaysia. In Maizatul Haizan Mahbob, \& Mohamad Zain Musa (Eds.), Tinjauan baru politik Malaysia (pp. 66-95). Bangi: Penerbit Universiti Kebangsaan Malaysia.

Md Ishak Ismail, \& Nur Fai'zah Abdul Bakar (n.d.). Tadbir urus korporat: Peranan dan kepentingan terhadap sektor korporat. Retrieved May 23, 2011, from http://www.micg.net/research.htm

Mohd Najib Abdul Razak. (2010). A speech at Majlis Pelan Halatuju Program Transformasi Kerajaan. Retrieved May 23, 2011, from http://www.kabinet.gov.my

Norliza Wasilan. (2011). Saya Tak Halalkan, Nik Aziz. Retrieved March 18, 2011, from http://www.bharian.com.my 
Ramanathan, K. (2002). Konsep asas pentadbiran awam. Kuala Lumpur: Dewan Bahasa dan Pustaka.

Sidang Pengarang ILBS. (1992). Malaysia kita: Panduan dan rujukan untuk peperiksaan am kerajaan. Kuala Lumpur: International Law Book Services.

Sity Daud. (1999). Pemerintah berorientasikan pembangunan. In Ghazali Mayudin (Ed.), Teori sains politik pilihan: Aplikasinya dalam konteks Malaysia (pp. 220-231). Bangi: Penerbit Universiti Kebangsaan Malaysia.

Sity Daud. (2002). Ekonomi politik pembangunan: Teori strukturalis dan kritikan neoliberal. In Ghazali Mayudin (Ed.), Politik Malaysia: Perspektif teori dan praktik (pp. 257-271). Bangi: Penerbit Universiti Kebangsaan Malaysia.

Sity Daud. (2006). Negara dan ideologi pembangunan. In Ghazali Mayudin, Jamie Hamil, Sity Daud, \& Zaini Othman (Eds.), Demokrasi, kepimpinan dan keselamatan dalam politik Malaysia (pp. 152-170). Bangi: Penerbit Universiti Kebangsaan Malaysia. 